\title{
PENGARUH MODEL PEMBELAJARAN INQUIRY TRAINING TERHADAP KETERAMPILAN PROSES SAINS SISWA PADA PELAJARAN FISIKA
}

\author{
Abdul Hakim, Aisyah ${ }^{1}$ \\ email: aisyahaisyah228@gmail.com ${ }^{1}$
}

\begin{abstract}
Abstrak. Penelitian ini bertujuan untuk mengetahui hasil keterampilan proses sains siswa dan aktivitas belajar melalui penerapan model pembelajaran inquiry training dan pembelajaran konvensional pada materi pokok suhu, kalor, dan perpindahan kalor. Penelitian ini merupakan quasi eksperiment dengan desain two group pre-test dan pos-test. Populasi penelitian ini adalah seluruh siswa kota madya medan. Teknik yang digunakan dalam pengambilan sampel penelitian adalah cluster random sampling, yaitu kelas eksperimen menggunakan model pemebelajaran inquiry training dan kelas kontrol menggunakan pembelajaran konvensional. Instrumen penelitian berupa tes keterampilan proses sains, aktivitas belajar, sikap dan keterampilan siswa berupa lembar penilaian yang digunakan oleh observer. Hasil analisis data menjelaskan bahwa uji model pembelajaran inquiry training lebih berpengaruh dalam meningkatkan keterampilan proses sains siswa daripada pembelajaran konvensional.
\end{abstract}

Katakunci: Inquiry Training, Keterampilan Proses Sains Siswa.

\section{THE EFFECT OF THE INQUIRY TRAINING MODEL TOWARDS SCIENCE PROCESS SKILLS OF STUDENTS ON PHYSICS LESSON}

\author{
Abdul Hakim, Aisyah ${ }^{1}$ \\ email: aisyahaisyah228@gmail.com ${ }^{1}$
}

\begin{abstract}
This study aimed to know the effect of science process skills of students and activity among the inquiry training and the conventional learning. This research is quasi-experimental study using pre-test and post-test design. The population of the study was students in Medan. Techniques that used to gain a simple is cluster random sampling, the first was grade as experimental class used the inquiry training model and the second was grade as the control class used the conventional learning. The instruments of this study were the science process skills test. The activity, affective, and psychomotor was used observation sheet. The analysis results that the inquiry training was better than that conventional learning in improving the science process skills of students.
\end{abstract}

Keywords: Inquiry Training, Science Process Skills of Students

\section{PENDAHULUAN}

Mutu pendidikan di Indonesia masih rendah jika dibandingkan dengan negara-negara lain. Menurut hasil penelitian Programme for International Student
Assessment (PISA) Indonesia (dalam Wulandari, 2015) menunjukkan hasil yang tidak banyak perubahan. Pada tahun 2003, dalam bidang matematika, Indonesia berada di peringkat 38 dari 41 negara dengan rataan 
A. Hakim dan Aisyah: Pengaruh Model Pembelajaran Inquiry Training Terhadap Keterampilan Proses Sains Siswa pada Pelajaran Fisika

skor 360. Pada tahun 2006 rataan skor siswa naik menjadi 391 dengan peringkat 50 dari 57 negara. Pada tahun 2009 Indonesia menempati peringkat 61 dari 65 negara dengan rataan turun menjadi 371 sementara rataan skor internasiol adalah 496. Pada tahun 2012 Indonesia berada di peringkat 62 dari 63 negara dengan skor 375. Hasil dari beberapa kali mengikuti tes tersebut menunjukkan bahwa Indonesia selalu berada di posisi bawah dalam setiap keikutsertaannya. Sedangkan menurut Trends in International Mathematics and Science Study (TIMSS) 2007, Peringkat sains Indonesia berada di peringkat 39 dari 41 negara dengan skor 308. Tahun 2011, Indonesia berada di peringkat 38 dari 42 negara dengan skor 386 . Hal ini menunjukkan bahwa kemampuan sains dan matematika siswa di Indonesia masih di bawah rata-rata dari negara lain.

Fisika sebagai salah bagian dari sains dimasukkan dalam kurikulum pelajaran di Indonesia mulai dari tingkat dasar sampai menengah. Pembelajaran sains fisika membawa perubahan karakter bagi siswa dan memperkaya karakter dan personalitinya (Rao, 2007). Fisika sebagai penyusun sains adalah sarana untuk melatih para siswa agar dapat menguasai pengetahuan, konsep dan prinsip fisika, memiliki kecakapan ilmiah, memiliki keterampilan proses sains siswa yang memperoleh pembelajaran fisika diharapkan nantinya akan memiliki sikap ilmiah sebagai komponen afektif, pengetahuan/wawasan sains sebagai komponen kognitif serta memiliki keterampilan proses sains sebagai komponen psikomotorik.

Berdasarkan studi pendahuluan yang dilakukan di peroleh bahwa : (1) Nilai UN pada mata pelajaran fisika tidak mengalami peningkatan yaitu 8,57 dan 8,57 (2) Kriteria ketuntasan minimal (KKM) adalah 60 jika dibandingkan dengan sekolah masih rendah; (3) Nilai rata-rata hasil ujian harian fisika siswa semester sebesar 54 dan nilai rata-rata hasil ujian fisika semester I siswa semester I sebesar 50; (3) Siswa masih cenderung menghafal teori, konsep - konsep, dan rumus serta tidak didasarkan pada pengalaman siswa; (4) Kegiatan pembelajaran fisika yang dilaksanakan belum bisa memfasilitasi siswa untuk mengembangkan keterampilan proses sainsnya dikarenakan guru masih menggunakan metode ceramah, mencatat, dan mengerjakan soal; (5) Kegiatan pembelajaran sangat jarang melakukan eksperimen karena hal tersebut membutuhkan waktu yang lebih lama. Berdasarkan angket yang diberikan kepada 38 siswa diperoleh sebanyak 89,5\% (34 siswa) dapat menjelaskan pengertian hipotesis tetapi siswa tidak dapat merumuskan hipotesis dan memberikan contoh rumusan hipotesis; sebanyak 89,5\% (34 siswa) menyatakan guru menyampaikan masalah yang berkaitan berkaitan dengan materi tetapi siswa tidak dapat memberikan contoh masalah; sebanyak 94,4\% (36 siswa) tidak dapat menyelesaikan masalah dalam
Jurnal Pendidikan Fisika p-ISSN2252-732X e-ISSN 2301-7651

pelajaran fisika; sebanyak 94,7\% (36 siswa) tidak bisa menemukan berdasarkan data atau informasi; sebanyak $60,5 \%$ (23 siswa) menyatakan dapat menganalisis suatu masalah tetapi hanya $5,2 \%$ yang dapat memberikan contoh analisis masalah; dan sebanyak $97,4 \%$ (37 siswa) tidak dapat menarik kesimpulan. Masalah di atas merupakan gambaran kurangnya tingkat kemampuan siswa menguasai materi berupa konsep-konsep materi pelajaran serta aplikasinya dalam bentuk soal-soal pelajaran.

Berhubungan dengan masalah tersebut maka dipilih model pembelajaran inqury training. Menurut (Hakim \& Cibro, 2012) Model pembelajaran Inquiry Training diharapkan dapat mengatasi permasalahan tersebut. karena rangkaian kegiatan pembelajaran Inquiry Training menekankan pada proses berpikir secara kritis dan analitis untuk mencari dan menemukan sendiri jawaban dari suatu masalah (Sirait 2012). Model pembelajaran Inquiri Training memiliki lima tahap pembelajaran, yaitu: (1) menghadapkan pada masalah; (2) merumuskan hipotesis; (3) mengumpulkan data-eksperiment; (4) mengolah dan mempormulasikan data-eksperiment; (5) menganalisa proses penelitian.

Model pemebelajaran Inqury training pernah diteliti diantaranya Khalid \& Azeem (2012) menyatakan bahwa model pembelajaran inquiry training yang diberikan oleh guru dapat membantu kegiatan pembelajaran siswa dimana siswa dapat merumuskan dan menguji ide-ide mereka, menarik kesimpulan dan menyampaikan pengetahuan mereka. Menurut Hayati \& Retno (2013 ; 26) inquiry training membawa siswa secara langsung ke dalam proses ilmiah melalui latihan-latihan yang memadatkan proses ilmiah Hifni \& Turnip (2015) memiliki dampak terhadap peningkatan kemampuan berpikir kritis dan keterampilan proses sains. Hidayat \& Harahap (2015) mengajukan pertanyaan atau permasalahan, merumuskan hipotesis, mengumpulkan, menganalisis data dan menyimpulkan mengalami peningkatan, Vaishnav (2013) hasil belajar melalui subjek percobaan, dan merumuskan ide-ide baru meningkat.

\section{METODE PENELITIAN}

Penelitian ini termasuk jenis penelitian quasi eksperimen dan desain penelitian yang digunakan adalah control group pretest-postest design. Rancangan penelitian ini ditunjukkan pada Tabel 1.

Pelaksanaan penelitian di awali dengan memberikan pretest kepada kelas eksperimen dan kelas kontrol. Setelah data pretest diperoleh, dilakukan analisis data yaitu uji normalitas menggunakan uji lillifors, uji homogenitas menggunakan uji varians, dan uji $\mathrm{t}$ dua pihak untuk mengetahui kemampuan awal siswa pada kedua kelompok sampel. Dalam hal ini, kemampuan awal kedua siswa harus sama. Selanjutnya menyampaikan materi pokok suhu, kalor dan perpindahan kalor dengan menggunakan model 
A. Hakim dan Aisyah: Pengaruh Model Pembelajaran Inquiry Training Terhadap Keterampilan Proses Sains Siswa pada Pelajaran Fisika

pembelajaran inquiry training pada kelas eksperimen dan pada kelas kontrol menyampaikan dengan pembelajaran konvensional. Kemudian memberikan postest pada kedua kelas, setelah data postest diperoleh dilakukan analisis data yaitu uji normalitas, uji homogenitas, dan uji $\mathrm{t}$ satu pihak untuk mengetahui pengaruh model pembelajaran inquiry training. Jika analisis statistik menunjukkan hasil belajar siswa pada kelas eksperimen lebih tinggi daripada hasil belajar siswa di kelas kontrol, maka ada pengaruh model pembelajaran inquiry training terhadap hasil belajar siswa.

Tabel 1. Desain Penelitian

\begin{tabular}{|l|c|c|c|}
\hline \multicolumn{1}{|c|}{ Kelas } & Pretest & Perlakuan & Posttest \\
\hline Eksperimen & $\mathrm{T}$ & $\mathrm{X}$ & $\mathrm{T}$ \\
\hline Kontrol & $\mathrm{T}$ & $\mathrm{Y}$ & $\mathrm{T}$ \\
\hline \multicolumn{2}{|c|}{ (Sukmadinata 2012) }
\end{tabular}

Keterangan:

$$
\begin{aligned}
\mathrm{T}= & \text { Pemberian tes hasil belajar } \\
\mathrm{X}= & \text { Perlakuan dengan menggunakan model } \\
& \text { pembelajaran Inquiry Training } \\
\mathrm{Y} \quad= & \text { Perlakuan dengan menggunakan } \\
& \text { pembelajaran konvensional }
\end{aligned}
$$

\section{HASIL DAN PEMBAHASAN}

Setelah kedua kelas diberikan perlakuan yang berbeda, kedua kelas diberikan postes. Untuk melihat secara rinci hasil postes kedua kelas dapat dilihat pada Gambar 1.

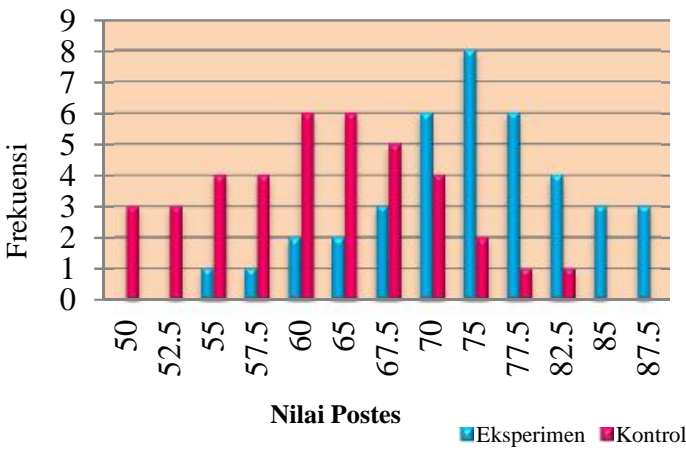

Gambar 1. Diagram Batang Nilai Postes Kelas Eksperimen dan Kelas Kontrol

Setelah dilakukan postes di lakukan uji hipotesis satu pihak untuk melihat ada pengaruh yang signifikan dengan kriteria pengujian $\mathrm{H}_{\mathrm{o}}$ jika $\mathrm{t}<\mathrm{t}_{1-\alpha}$, dimana $\mathrm{t}_{1-\alpha}$ di dapat dari daftar distribusi t dengan $\mathrm{dk}=\left(\mathrm{n}_{1}+\mathrm{n}_{2}-2\right)$ dan peluang $\left(\mathrm{t}_{1-\alpha}\right)$ dan $\alpha=0,05$. Jika $\mathrm{t}$ mempunyai hargaharga lain $\mathrm{H}_{\mathrm{o}}$ di tolak. Hasil pengujian hipotesis dapat dilihat pada Tabel 2 .

Berdasarkan Tabel 2 diperoleh bahwa untuk nilai postes $t_{\text {hitung }}>t_{\text {tabel }}$ yaitu 6,55>1,67 maka Ha diterima.
Jurnal Pendidikan Fisika p-ISSN2252-732X e-ISSN 2301-7651

Hal ini dapat disimpulkan bahwa ada perbedaan yang signifikan antara keterampilan proses sains siswa dengan menerapkan model pembelajaran inquiry training dengan model pembelajaran konvensional pada materi pokok suhu, kalor, dan perpindahan kalor.

Tabel 2. Ringkasan Perhitungan Uji t Data Pretes dan Postes

\begin{tabular}{|c|c|c|c|c|}
\hline \multirow{2}{*}{ Data } & \multicolumn{2}{|c|}{ Pretes } & \multicolumn{2}{c|}{ Postes } \\
\cline { 2 - 5 } & Eks & Kont & Eks & Kont \\
\hline Rata-rata & 38,33 & 38,27 & 74,29 & 62,43 \\
\hline $\mathrm{t}_{\text {titung }}$ & \multicolumn{2}{|c|}{0,18} & \multicolumn{2}{|c|}{6,55} \\
\hline $\mathrm{t}_{\text {tabel }}$ & \multicolumn{2}{|c|}{1,99} & \multicolumn{2}{c|}{1,67} \\
\hline Kesimpulan & $\begin{array}{c}\text { Kemampuan awal } \\
\text { sama }\end{array}$ & $\begin{array}{c}\text { Ada penganh yang } \\
\text { signifikan }\end{array}$ \\
\hline
\end{tabular}

Observasi bertujuan untuk mengamati aktivitas belajar siswa selama pembelajaran dengan model pembelajaran inquiry training. Observasi dilakukan dengan tiga observer yaitu dua rekan peneliti dan guru mata pelajaran. Observasi dilakukan selama kegiatan belajar mengajar yang terdiri dari dua kali pertemuan. Perkembangan aktivitas siswa di kelas eksperimen mengalami peningkatan selama menerima pembelajaran dengan model inquiry training yaitu peningkatan aktivitas belajar siswa dari pertemuan I sampai pertemuan III dengan rata-rata nilai seluruhnya adalah 63,19 dengan kriteria penilaian aktif. Hasil observasi aktivitas pada kelas eksperimen menunjukkan ada pengaruh aktivitas terhadap keterampilan proses sains berdasarkan kategori, individu dan kelompok. Adapun pengaruh aktivitas berdasarkan kategori yang paling rendah sampai yang paling tinggi ditunjukkan pada Gambar 2. Hasil observasi pengaruh aktivitas terhadap hasil belajar berdasarkan individu ditunjukkan pada Gambar 3. Hasil observasi pengaruh aktivitas terhadap hasil belajar berdasarkan kelompok ditunjukkan pada Gambar 4. Hasil Observasi perkembangan keterampilan proses sains siswa: (1) indikator mengobservasi pada deksriptor mampu melakukan pengamatan baik secara langsung maupun tidak langsung (melalui perhitungan dan menggunakan fakta) pada pertemuan ketiga yaitu 64\% (25 siswa), pertemuan 2 yaitu 51,28\% (20 siswa) dan pada pertemuan 1 tidak ada siswa yang mampu.

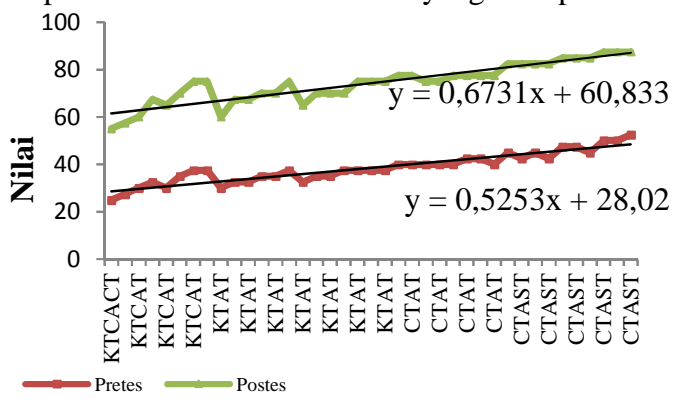

Gambar 2. Grafik pengaruh aktivitas terhadap hasil belajar berdasarakan kategori. 
A. Hakim dan Aisyah: Pengaruh Model Pembelajaran Inquiry Training Terhadap Keterampilan Proses Sains Siswa pada Pelajaran Fisika

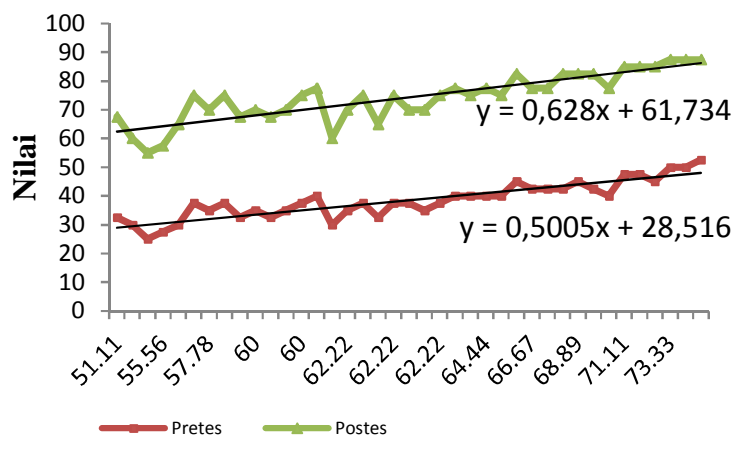

Gambar 3. Grafik pengaruh aktivitas terhadap hasil belajar berdasarakan individu.

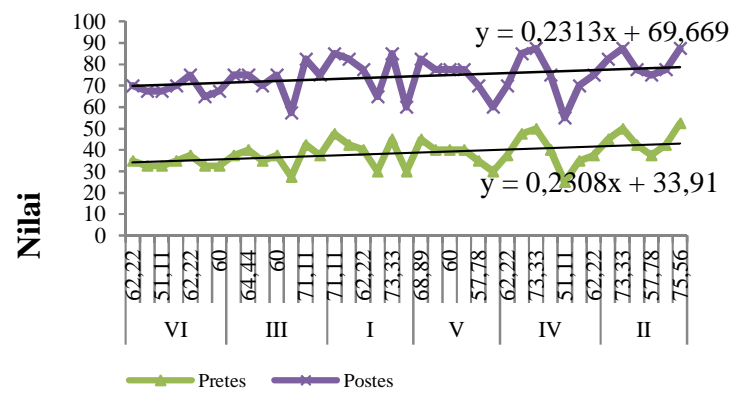

Gambar 4. Grafik pengaruh aktivitas terhadap hasil belajar berdasarakan kelompok.

Pada deksriptor pengamatan dilakukan dengan kemampuan sendiri lebih menonjol pada pertemuan 1 yaitu $100 \%$ (39 siswa) jika dibandingkan dengan pertemuan 2 yaitu 48,72\% (19 siswa) dan pertemuan 3 yaitu $35,9 \%$ (14 siswa). Deksriptor pengamatan dilakukan dengan tepat dan deksritor tidak melakukan pengamatan tidak ada siswa yang memenuhi kriteria. Hal ini berarti dalam indikator mengobservasi siswa masih individualis. (2) Indikator mengumpulkan data pada deksriptor mengumpulkan dan mencatat data dengan benar pada pertemuan 3 yaitu 5,12\% (2 siswa) sedangkan pada pertemuan 1 dan 2 tidak memenuhi kriteria, deksriptor menemukan prosedur yang harus dilakukan dalam percobaan lebih menonjol pada pertemuan ketiga yaitu $89,74 \%$ (35 siswa) sedangkan pada pertemuan 1 adalah $48,72 \%$ (19 siswa) dan pertemuan 2 adalah $69,23 \%$ (27 siswa). Deksriptor memilih instrumen yang tepat untuk mengolah data pada pertemuan 1 yaitu $51,28 \%$ (20 siswa) sedangkan pertemuan 2 yaitu 30,77\% (12 siswa), dan pertemuan 3 yaitu 5,12\% (2 siswa). Deksriptor tidak dapat mengumpulkan data adalah tidak ada siswa yang memenuhi kriteria. Hal ini menunjukkan kemampuan siswa masih lebih banyak pada menemukan prosedur yang harus dilakukan dengan bantuan guru. (3) indikator mengolah data pada deksriptor mengolah data dalam bentuk grafik, gambar, maupun tabel yaitu tidak ada
Jurnal Pendidikan Fisika p-ISSN2252-732X e-ISSN 2301-7651

siswa yang memenuhi kriteria. Siswa lebih menonjol pada deksriptor pemaparan pengamatan dengan menggunakan perbendaharaan kata yang sesuai pada pertuan 3 yaitu 94,87\% (37 siswa) sedangkan pada pertemuan 1 yaitu 48,72\% (19 siswa) dan pertemuan 2 $89,74 \%$ (19 siswa). Deksriptor menentukan hasil pengukuran dalam percobaan pada pertemuan 1 yaitu $51,28 \%$ (20 siswa), pertemuan 2 yaitu 10,26\% (4 siswa), dan pertemuan 3 yaitu 7,69\% (3 siswa). Dekriptor tidak dapat mengolah data yaitu tidak ada yang memenuhi kriteria pada setiap pertemuan, Hal ini berarti siswa lebih menonjol pada penemuan menggunakan perbendaharan kata. (4) indikator mengidentifikasi dan mengontrol variabel-variabel pada deksriptor membandingkan hasil percobaan yang benar dan salah dengan tepat yaitu tidak seorangpun yang memenuhi kriteria pada setiap pertemuan. Deskriptor mencari persamaan dan perbedaan dari alat yang digunakan pada pertemuan 1 yaitu $20,51 \%$ (8 siswa), pertemuan 2 yaitu $10,26 \%$ (4 siswa), dan pertemuan 3 yaitu 43,59\% (17 siswa). Siswa lebih menonjol pada deksriptor mengurutkan pelaksanaan percobaan dengan benar yaitu pada pertemuan 2 adalah $89,74 \%$ (35 siswa), pertemuan 1 yaitu 79,49\% (31 siswa), dan pertemuan 3 yaitu 56,41\% (22 siswa). Deksriptor tidak dapat megidentifikasi dan mengotrol variabel tidak ada siswa yang memenuhi kriteria. Hal ini menunjukkan siswa lebih menonjol dalam melakukan urutan percobaan dengan baik. (5) Merumuskan dan meguji hipotesis dengan penjelasan pada deksriptor mampu mengajukan perkiraan penyebab terjadinya hasil praktikum pada pertemuan 1 tidak ada yang memenuhu kriteria, pada pertemuan 2 yaitu 7,69\% (3 siswa), dan pertemuan 3 yaitu 17,94\% (7 siswa). Siswa lebih menonjol pada deksriptor hipotesis yang dibuat berasal dari pemikiran sendiri yaitu pada pertemuan 2 adalah $84,61 \%$ (33 siswa) sedangkan pada pertemuan 1 dan 3 adalah 82,05\% (32 siswa). Deksriptor hipotesis yang diberikan sesuai pada pertemuan 1 yaitu 17,95\% (7 siswa), pertemuan 2 yaitu 7,69\% (3 siswa), dan pertemuan 3 tidak ada yang memenuhi kiteria begitupun dengan dengan dekriptor tidak dapat memberikan hipotesis. Hal ini menunjukkan siswa menonjol dalam mengeluarkan pendapat. (6) Menarik kesimpulan pada deksriptor kesimpulan dibuat berdasarkan hasil percobaan yang dilakukan pada pertemuan 1 tidak ada yang memenuhi kriteria, pertemuan 2 yaitu 10,26\% (4 siswa), dan pertemuan 3 yaitu 17 siswa 43,59\% (17 siswa). Siswa lebih dominan pada deksriptor kesimpulan dibuat pada pemikiran sendiri yaitu 87,18\% (34 siswa), pertemuan 2 yaitu $84,61 \%$ (33 siswa), pertemuan $356,41 \%$ (22 siswa). Deksriptor kesimpulan dibuat sesuai materi yang dipraktikumkan pada pertemuan 1 yaitu $12,82 \%$ (5 siswa), pertemuan 2 yaitu 5,13\% (2 siswa), sedangkan pada pertemuan 3 tidak ada yang memenuhi kriteria begitupun pada deksriptor tidak dapat menarik kesimpulan. Hal ini menunjukkan bahwa siswa masih kurang maksimal dalam melakukan praktikum bersama kelompok masing-masing. 
A. Hakim dan Aisyah: Pengaruh Model Pembelajaran Inquiry Training Terhadap Keterampilan Proses Sains Siswa pada Pelajaran Fisika

\section{PEMBAHASAN}

Dari Gambar 1 ada peningkatan sebanyak 3 digit. Persamaan linier $\mathrm{y}=\mathrm{ax}+\mathrm{b}$ memiliki nilai a yang menyatakan kemiringan garis. Jika dilihat dari grafik, nilai a pada $\mathrm{y}_{\text {post }}=0,673 \mathrm{x}+60,833$ lebih besar dibandingkan dengan nilai a pada $\mathrm{y}_{\text {pre }}=0,5253+28,02$. Nilai a pada persamaan linier pretes $\left(\mathrm{a}_{\text {pre }}\right)$ menjadi acuan kriteria dalam menentukan berpengaruh atau tidaknya nilai aktivitas. Adapun kriterianya adalah sebagai berikut : (1) $a_{\text {post }}>a_{\text {pre }}$ : nilai aktivitas mempengaruhi hasil belajar (nilai postes), (2) $\mathrm{a}_{\text {post }}<\mathrm{a}_{\text {pre }}$ : nilai aktivitas tidak mempengaruhi hasil belajar (nilai postes). Pada grafik diatas menunjukkan $a_{\text {post }}>a_{\text {pre }}$ yang berarti nilai aktivitas mempengaruhi hasil belajar (nilai postes), meskipun perbedaan nilai $\mathrm{a}_{\text {pre }}$ dan $\mathrm{a}_{\text {post }}$ sangat sedikit.

Menurut gambar 2 menunjukkan peningkatan aktivitas sebanyak 2 digit. Persamaan linier $y=a x+b$ memiliki nilai a yang menyatakan kemiringan garis. Jika dilihat dari grafik, nilai a pada $\mathrm{y}_{\text {post }}=0,628 \mathrm{x}+61,734$ lebih besar dibandingkan dengan nilai a pada $\mathrm{y}_{\text {pre }}=$ $0,5005 x+28,516$. Hal ini menunjukkan $a_{\text {post }}>a_{\text {pre }}$ yang berarti nilai aktivitas mempengaruhi hasil belajar (nilai postes) secara individu meskipun perbedaan nilai $a_{\text {pre }}$ dan $\mathrm{a}_{\text {post }}$ sangat kecil.

Menurut gambar 3 menunjukkan peningkatan aktivitas sebanyak 1 digit. Persamaan linier $y=a x+b$ memiliki nilai a yang menyatakan kemiringan garis. Jika dilihat dari grafik, pada $\mathrm{y}_{\text {post }}=0,2313 \mathrm{x}+69,669$ memiliki nilai a yang lebih besar dibandingkan dengan nilai a pada $y_{\text {pre }}=0,2308 x+33,91$. Hal ini berarti $a_{\text {post }}>$ $\mathrm{a}_{\text {pre }}$ yang berarti nilai aktivitas mempengaruhi hasil belajar (nilai postes) secara kelompok, meskipun perbedaan nilai $a_{\text {pre }}$ dan $a_{\text {post }}$ sangat kecil.

Secara teori Gambar 4 yang seharusnya memberikan perbedaan lebih banyak karena model inquiry training adalah model pembelajaran yang diterapkan dengan cara berkelompok. Dapat disimpulkan bahwa aktivitas belajar mempengaruhi keterampilan proses sains siswa namun tidak ada pengaruh model pembelajaran inquiry training jika dilihat secara individu maupun secara kelompok sehingga pelaksanaan model inquiry training dalam penelitin ini kurang maksimal.

Dilihat dari hasil observasi perkembangan keterampilan proses sains menurut model pembelajaran inquiry training yaitu Joyce (2011) mengobservasi, mengumpulkan data, mengolah data, mengidentifikasi dan mengotrol variabel, merumuskan dan menguji hipotesis dengan penjelasan, dan menarik kesimpulan, peningkatan keterampilan proses sains tidak tersebar merata. Sehingga masih sangat diperlukan perbaikan atau penekanan pada setiap indikator keterampilan proses sains.

Dari gambar 2, 3, dan 4 serta observasi perkembangan keterampilan proses sains diperoleh bahwa nilai aktivitas pada kelas eksperimen memberikan sumbangan terhadap keterampilan proses
Jurnal Pendidikan Fisika p-ISSN2252-732X e-ISSN 2301-7651

sains. Artinya setelah diterapkan model inquiry training terhadap keterampilan proses sains siswa menjadi meningkat dan berbeda secara signifikan dibandingkan dengan kelas kontrol. Hal ini sesuai dengan hasil penelitian terdahulu Remziye (2011) menyatakan terdapat perbedaan yang signifikan keterampilan proses sains siswa dan sikap ilmiah yang menggunakan model belajar inquiry training. Silitonga, Harahap, \& Derlina (2012) model pembelajaran inquiry training lebih efektif dalam meningkatkan keterampilan proses sains siswa. Hidayat dan Harahap (2015) mengajukan pertanyaan atau permasalahan, merumuskan hipotesis, mengumpulkan, menganalisis data dan menyimpulkan mengalami peningkatan. Hifni \& Turnip (2015) memiliki dampak terhadap peningkatan kemampuan berpikir kritis dan keterampilan proses sains siswa.

\section{KESIMPULAN}

Hasil perhitungan uji $t$ diperoleh bahwa $t_{\text {itung }}>t_{\text {tabel }}$ maka Ha di terima yang berarti ada perbedaan yang signifikan antara hasil belajar siswa dengan model inquiry training dan pembelajaran konvensional pada materi pokok suhu, kalor, dan perpindahan kalor. Berdasarkan pembahasan dapat disimpulkan bahwa ada perbedaan yang signifikan jika nilai pretes, aktivitas, dan postes diurutkan berdasarkan kategorinya. Namun tidak ada pengaruh model pembelajaran inquiry training jika dilihat secara individu maupun secara kelompok.

\section{SARAN}

Jika ditinjau secara individu dan secara kelompok, aktivitas berpengaruh kecil terhadap hasil belajar, peneliti selanjutnya hendaknya memperhatikan sintaks dalam kegiatan belajar mengajar, pembagian kelompok, dan memperbaiki deksriptor observasi keterampilan proses sains siswa yaitu mengobservasi, mengumpulkan data, mengolah data, mengidentifikasi dan mengontrol variabel, merumuskan dan menguji hipotesis dengan penjelasan, dan menarik kesimpulan.

\section{REFERENSI}

Hakim, A. S. \& Cibro, N. A. (2013) Perbedaan Hasil Belajar Siswa Dengan Model Pembelajaran Inquiry Training Dan Model Pembelajaran Konvensional pada Materi Pokok Listrik Dinamis Di Sma Negeri 1 Takengon T.P 2012/2013. Jurnal Inpafi, 321

Hayati \& Suyanti, R. D. (2013). Efek Model Pembelajaran Inquiry Training Berbasis Multimedia dan Motivasi Terhadap Hasil Belajar Fisika Siswa. Jurnal Online Pendidikan Fisika, 26

Hidayat, M. I. \& Harahap, M. B. (2015). Efek Model Pembelajaran Inquiry Training Berbasis Multimedia Lectora dan Kemampuan Berpikir Formal Terhadap Hasil Belajar Fisika Siswa. Jurnal Pendidikan Fisika. 29-31 
A. Hakim dan Aisyah: Pengaruh Model Pembelajaran

Jurnal Pendidikan Fisika Inquiry Training Terhadap Keterampilan Proses Sains Siswa pada Pelajaran Fisika

p-ISSN2252-732X

e-ISSN 2301-7651

Hifni, M. \& Turnip, B.M. Efek Model Pembelajaran Inquiry Training Menggunakan Media Macromedia Flash Terhadap Keterampilan Proses Sains Dan Kemampuan Berpikir Logis, Jurnal Pendidikan Fisika, 15-16

International Association for the Evaluation of Educational Achievement. (2012). Highlights From The Trends in International Mathematics and Science Study (TIMSS) 2011. HSRC: South Africa

Joyce, Bruce, \& Marsha W. (2011). Model-Model Pembelajaran, Edisi Kedelapan, (Diterjemahkan oleh : Fawaid, A., \& Mirza, A.). Yogyakarta: Penerbit Pustaka Belajar

Khalid, A. \& Azeem, M. (2012) Constructivist VS Traditional: Effective Instructional Approach In Teacher Education. International Journal of Humanities and Social Science. 171

Rao, B. dan Digumarti. (2008). Science Proccess Skills of School Students. New Delhi: Aurora Offset.

Remziye, E. (2011). The Effects of Inquiry-Based Science Teaching On Elementary School Students' Science Process Skills and Science Attitude. Bulgarian Journal of Science and Education Policy (BJSEP), 23

Silitonga, P. Harahap M.B. \& Derlina (2012). Pengaruh Model Pembelajaran Inquiry Training dan Kreativitas Terhadap Keterampilan Proses Sains. Jurnal Pendidikan Fisika, 48-49

Sirait, R. (2012). Pengaruh Model Pembelajaran Inquiry Training Terhadap Hasil Belajar Siswa pada Materi Pokok Usaha dan Energi Kelas VIII MTs N 3 Medan. Jurnal Pendidikan Fisika, 23-25

Sukmadinata, N. S. (2012). Metode Penelitian Pendidkan. Penerbit PT Remaja Rosdakarya

Vaishnav, R.S. (2013). Effectiveness of Inquiry Training Model for Teaching Science, SRJIS, 1218 - 1219

Wulandari, C. I. (2015). Uji Coba Soal PISA untuk Mengetahui Tingkat Kemampuan Literasi Matematis pada Siswa SMP. repository.upi.edu,perpustakaan.upi.edu. 58 